\title{
$\beta_{3}$-Adrenergic receptor Trp64Arg polymorphism and increased body mass index in sleep apnoea
}

\author{
J. Piérola*, A. Barceló*, M. de la Peña*, F. Barbé\#, ${ }^{\#, ~ J . B . ~ S o r i a n o ~}{ }^{+, \S}$, \\ A. Sánchez Armengol ${ }^{f}$, C. Martínez ${ }^{\# \#}$ and A. Agustíi,,+
}

ABSTRACT: Obesity is an important risk factor for obstructive sleep apnoea syndrome (OSAS), insulin resistance and cardiovascular disease. The substitution of tryptophan 64 with arginine (Trp64Arg) polymorphism (Arg variant) of the $\beta_{3}$-adrenergic receptor (ADRB3) has been associated with obesity. In this study, the prevalence of the Trp64Arg ADRB3 polymorphism in a large group of patients with OSAS and its association with body mass index (BMI), insulin resistance and hypertension were evaluated.

ADRB3 genotype was determined in 387 patients with OSAS and 137 healthy subjects recruited from three Spanish tertiary hospitals.

The distributions of the ADRB3 genotypes were similar in OSAS and controls, and, in a multivariate model, the risk of OSAS was not associated with the presence of the Arg variant of the ADRB3 gene. However, BMI was higher in those patients with OSAS who carried this genetic variant than in those with the Trp variant. Furthermore, a linear trend for higher BMI was found in those with the Arg variant (56, 75 and 100\% for Trp/Trp, Trp/Arg and Arg/Arg, respectively). Insulin resistance, blood pressures and serum levels of lipids and glucose were not associated with the presence of the Arg variant of the ADRB3 gene.

The presence of the arginine 64 allele of the $\beta_{3}$-adrenergic receptor gene does not increase the risk of obstructive sleep apnoea syndrome, but is associated with the development of obesity in those patients who suffer obstructive sleep apnoea syndrome.

KEYWORDS: $\boldsymbol{\beta}_{3}$-Adrenergic receptor polymorphism, body mass index, sleep apnoea

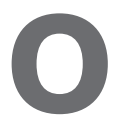

bstructive sleep apnoea syndrome (OSAS) is a common disorder characterised by excessive daytime sleepiness, repeated episodes of upper airway obstruction during sleep and nocturnal hypoxaemia [1]. Obesity is a risk factor for OSAS [2, 3], and it has been hypothesised that genetic variants that predispose to obesity might facilitate the development of OSAS [4, 5].

The $\beta_{3}$-adrenergic receptor (ADRB3) is mainly expressed in adipose tissue, and contributes to variations in energy expenditure and body fat distribution [6-8]. Polymorphisms of the ADRB3 have been suggested to participate in the pathogenesis of obesity [7, 9]. In particular, a single nucleotide polymorphism in the ADRB3 gene (substitution of tryptophan 64 with arginine (Trp64Arg)) has been associated with obesity, insulin resistance, abnormal lipid profile and arterial hypertension [10-15]. However, since the prevalence of the Trp64Arg mutation differs among ethnic groups [7], other studies have failed to show any relationship between this polymorphism and obesity $[16,17]$. Furthermore, it has been suggested that the association of this ADRB3 polymorphism with body weight and obesityrelated phenotypes may be dependent upon the presence of other susceptibility genes and/or exposure to other environmental factors [7].

The potential role of this polymorphism of the ADRB3 gene in OSAS had not been explored until recently, when it has been shown to be associated with obesity in male Chinese patients [18]. However, as the prevalence of the Trp64Arg mutation differs among ethnic groups [7], the present study was designed to: 1) estimate the prevalence of the Trp64Arg ADRB3 polymorphism in Spanish patients with OSAS; and 2) examine whether or not this gene variant was associated with other clinical phenotypes frequently present in patients with OSAS, such as obesity, insulin resistance and arterial hypertension.
AFFILIATIONS

*Serveis de Anàlisis Cliniques i Pneumologia, Son Dureta University Hospital, Palma de Mallorca,

${ }^{\#}$ Arnau de Vilanova University Hospital and

"Institut de Recerca Biomedica de Lleida, Lleida,

+Fundació Caubert-CIMERA, Illes Balears, Buñola,

${ }^{f}$ Hospital Virgen del Rocio, Seville,

\#\#Txagorritxu Hospital,

Vitoria-Gasteiz, and

${ }^{\text {s} C I B E R ~ E n f e r m e d a d e s ~ R e s p i r a t o r i a s, ~}$ Spain.

CORRESPONDENCE

A. Barceló

Serveis de Anàlisis Cliniques i

Pneumologia

Hospital Universitari Son Dureta

C/ Andrea Doria 55

07014 Palma de Mallorca

Spain

Fax: 34971175228

E-mail: abarcelo@hsd.es

Received:

November 232006

Accepted after revision:

July 052007

\section{SUPPORT STATEMENT}

This study was supported, in part, by ABEMAR, SEPAR and Fondo de Investigaciones Sanitarias (grants Red Respira (RTIC C03/11), 04/ 1593, 05/1059).

STATEMENT OF INTEREST None declared. 


\section{METHODS}

\section{Subjects and ethics}

The present case-control study was designed to determine the presence of the Trp64Arg mutation of the ADRB3 gene and its association with body mass index (BMI), lipid profile, glucose metabolism and the presence of arterial hypertension in a group of Spanish individuals with $(n=387)$ and without OSAS $(n=137)$. Participants were recruited and studied at the sleep units of three tertiary university hospitals in Spain (Son Dureta University Hospital, Palma de Mallorca; Hospital Virgen del Rocio, Seville; and Txagorritxu Hospital, Vitoria-Gasteiz). The diagnosis of OSAS was established by full polysomnography (E-Series; Compumedics, Abbotsford, Australia), and included recording of oronasal flow and thoracoabdominal movements, ECG, submental and pre-tibial electromyography, electrooculography, electroencephalography and transcutaneous measurement of arterial oxygen saturation. The apnoea/ hypopnoea index (AHI) was defined as the number of apnoeas plus hypopnoeas per hour of sleep. OSAS was diagnosed when the AHI was $\geqslant 10$ events $\cdot h^{-1}$. In controls, the diagnosis of OSAS was excluded by conventional polysomnography (in subjects whose BMI was $>30 \mathrm{~kg} \cdot \mathrm{m}^{-2}$ ) or a cardiorespiratory sleep study that recorded nasal flow, thoracic movements, cardiac frequency, snoring, body position and transcutaneous oxyhaemoglobin saturation (Edentec, Eden Prairie, MN, USA). Exclusion criteria (for both cases and controls) were presence of chronic obstructive pulmonary disease, liver cirrhosis, thyroid dysfunction, rheumatoid arthritis, chronic renal failure and/or psychiatric disorders.

Arterial hypertension was diagnosed if systolic blood pressure was $>140 \mathrm{mmHg}$ or diastolic blood pressure $>90 \mathrm{mmHg}$. Similarly, the threshold for diabetes was a glucose level of $>126 \mathrm{mg} \cdot \mathrm{dL}^{-1}$, for insulin resistance a homeostasis model assessment (HOMA) index of $>4$, for hyperlipidaemia a total cholesterol level of $>200 \mathrm{mg} \cdot \mathrm{dL}^{-1}$ and for obesity a BMI of $>30 \mathrm{~kg} \cdot \mathrm{m}^{-2}$.

The present study was approved by the ethics committees of the participating institutions, and all participants signed their consent after being fully informed of its goal and characteristics.

\section{Measurements}

Blood samples $(10 \mathrm{~mL})$ were obtained between 08:00 and 10:00 h after an overnight fast, and collected in tubes containing ethylenediamine tetra-acetic acid (EDTA) but no anticoagulant for biochemical determinations. After centrifugation, serum and plasma were immediately separated into aliquots and stored at $-80^{\circ} \mathrm{C}$. Blood in EDTA tubes and aliquots of serum and plasma were transported in dry ice from Txagorritxu Hospital and Virgen del Rocio Hospital to Son Dureta Hospital and stored at $-80^{\circ} \mathrm{C}$ until centralised analysis at the latter hospital.

\section{Biochemical analysis}

Glucose, triglyceride, cholesterol and high-density lipoprotein-cholesterol complex concentrations were determined by standard enzymatic methods using a Hitachi 917 biochemical analyser (Roche Diagnostics, Indianapolis, IN, USA). The plasma concentration of insulin was measured using a commercial chemiluminescent assay and an Immulite 2000 analyser (DPC, Los Angeles, CA, USA). Insulin resistance was calculated using HOMA [19].

\section{DNA extraction and genotyping}

DNA extraction of each blood sample was performed using a DNA extraction Kit (Wizard Genomic; Promega Corporation, Madison, WI, USA). The ADRB3 Trp64Arg polymorphism was genotyped using PCR. The PCR primers were 5'CAATACCGCCAACACCAGTGGG-3' and 5'-GGTCATGGTCTGGAGTCTCG-3'. PCR was carried out in a volume of $30 \mu \mathrm{L}$, containing $30 \mathrm{ng}$ genomic DNA, $2.0 \mathrm{mM} \mathrm{MgCl} 2,200 \mu \mathrm{M}$ deoxyribonucleoside triphosphates, $300 \mathrm{nM}$ each primer, 0.025 U EuroTaq DNA polymerase (Euroclone, Pero, Italy) and $1 \times$ reaction buffer. Amplified products were digested with 3 U Bacillus stearothermophilus NI (New England Biolabs, Beverly, MA, USA), and the resulting fragments separated on $3 \%$ agarose gels and visualised with ethidium bromide staining under ultraviolet illumination (Syngene Gen Genius; Synoptics Group, Cambridge, UK)

\section{Statistical analysis}

Results are presented as mean \pm SD. Comparisons between groups were performed with independent ANOVA tests for quantitative variables and Fisher's exact Chi-squared test for proportions. Correlations between variables were explored using the Spearman test. The Hardy-Weinberg equilibrium for allelic distribution was tested using the formula, $1=p^{2}+2 p q+q^{2}$, where $\mathrm{p}$ and $\mathrm{q}$ are the allelic frequencies of the Trp and Arg variants, respectively [20]. The risk of being a carrier of the Arg variant of the ADRB3 polymorphism was quantified with an odds ratio in patients with OSAS versus controls, and the $95 \%$ confidence interval calculated. Finally, multivariate logistic regression analysis was conducted, including carrier status and number of comorbid conditions. A p-value of $<0.05$ was considered significant.

\section{RESULTS}

Patients with OSAS $(n=387)$ and healthy controls $(n=137)$ were studied. Table 1 shows the main demographic and clinical characteristics and biochemical profile of all subjects studied. Patients with OSAS were older and had significantly higher BMIs and systolic and diastolic blood pressures, glucose levels, triglyceride levels and HOMA indices than controls $(p<0.05$ for all). Differences in insulin level were of borderline significance $(p=0.056)$, and there were no differences in cholesterol level.

Table 2 presents the distribution of genotypes and allelic frequencies of the observed ADRB3 variants in all participants. The genotypic frequency distributions were in HardyWeinberg equilibrium in both patients with OSAS and control subjects, and there were no differences between them $\left(\mathrm{X}^{2}=0.414\right)$. Furthermore, being a carrier of the Arg variant of the ADRB3 polymorphism did not significantly increase the risk of suffering OSAS (odds ratio 1.24; 95\% confidence interval $0.73-2.11 ; \mathrm{p}=0.514$; tables 2 and 3 ). However, it was found that patients with OSAS carrying the Arg variant of the ADRB3 gene exhibited higher BMIs than those with the Trp variant alone $(\mathrm{p}<0.01$; table 4$)$. By contrast, in control subjects, $\mathrm{BMI}$ did not differ according to the presence or absence of the Arg variant $\left(28.5 \pm 4.6\right.$ versus $\left.28.6 \pm 5.1 \mathrm{~kg} \cdot \mathrm{m}^{-2} ; \mathrm{p}=0.731\right)$. 


\begin{tabular}{|c|c|c|}
\hline \multirow[t]{2}{*}{ TABLE 1} & \multirow[b]{2}{*}{ OSAS } & \multirow[t]{2}{*}{$\begin{array}{l}\text { tructive sleep } \\
\text { trols }\end{array}$} \\
\hline & & \\
\hline Subjects $n$ & 387 & 137 \\
\hline Age yrs & $50 \pm 11^{\#}$ & $47 \pm 11$ \\
\hline Males \% & $87^{\#}$ & 76 \\
\hline$A H I$ events $\cdot h^{-1}$ & $51 \pm 24^{* * *}$ & $2 \pm 2$ \\
\hline $\mathrm{BMI} \mathbf{k g} \cdot \mathrm{m}^{-2}$ & $31.9 \pm 5.9^{\star \star \star}$ & $28.6 \pm 4.7$ \\
\hline SBP $\mathrm{mmHg}$ & $133 \pm 17^{\star \star \star}$ & $125 \pm 14$ \\
\hline DBP $\mathrm{mmHg}$ & $83 \pm 13^{\star * *}$ & $78 \pm 10$ \\
\hline Glucose $\mathrm{mg} \cdot \mathrm{dL}^{-1}$ & $108 \pm 23^{* \star *}$ & $97 \pm 16$ \\
\hline Triglycerides $\mathrm{mg} \cdot \mathrm{dL}^{-1}$ & $163 \pm 118^{\#}$ & $133 \pm 67$ \\
\hline Cholesterol $\mathrm{mg} \cdot \mathrm{dL}^{-1}$ & $212 \pm 41$ & $216 \pm 38$ \\
\hline $\mathrm{HDL}-\mathrm{C} \mathrm{mg} \cdot \mathrm{dL}^{-1}$ & $51 \pm 13$ & $53 \pm 12$ \\
\hline Insulin $\mu \mathrm{U} \cdot \mathrm{mL}^{-1}$ & $17 \pm 13$ & $14 \pm 14$ \\
\hline HOMA index & $4.6 \pm 3.9^{*}$ & $3.5 \pm 4.2$ \\
\hline Obesity \% & $60^{* * *}$ & 36 \\
\hline Hypercholesterolaemia \% & 62 & 66 \\
\hline Diabetes \% & $13^{\#}$ & 4 \\
\hline Insulin resistance $\%$ & $46^{\star \star \star}$ & 20 \\
\hline Hypertension \% & $40 * \star \star$ & 9 \\
\hline
\end{tabular}

Data are presented as mean \pm SD unless otherwise indicated. AHI: apnoea/ hypopnoea index; BMI: body mass index; SBP: systolic blood pressure; DBP: diastolic blood pressure; HDL-C: high-density lipoprotein-cholesterol complex; HOMA: homeostasis model assessment. ${ }^{*}: \mathrm{p}<0.005$. *: $p<0.05$; ***: $p<0.001$ versus healthy controls.

In patients with OSAS, the prevalence of obesity (BMI $>30 \mathrm{~kg} \cdot \mathrm{m}^{-2}$ ) increased linearly in carriers of the Arg variant of the ADRB3 gene (56, 75 and 100\% for Trp/Trp, Trp / Arg and Arg/Arg, respectively; $\mathrm{p}=0.001$ (trend) and 0.005 (Chi-squared test)). The corresponding BMIs were $31.5 \pm 5.7,33.5 \pm 6.9$ and $33.9 \pm 3.1$ for Trp/Trp, Trp/Arg and Arg/Arg, respectively $(p=0.038$ (trend)). Finally, a multivariate model was used to investigate whether carrier status influenced the clinical phenotype of OSAS, but no independent effect of the Arg

\begin{tabular}{llc} 
TABLE 2 & $\begin{array}{l}\text { Genotypic and allelic frequencies of the } \beta_{3^{-}} \\
\text {adrenergic receptor gene in patients with } \\
\text { obstructive sleep apnoea syndrome (OSAS) and } \\
\text { controls }\end{array}$ \\
& OSAS & Controls \\
\hline Subjects & 387 & 137 \\
Genotype & & \\
Trp/Trp & $316(82)$ & $116(85)$ \\
Trp/Arg & $67(17)$ & $21(15)$ \\
Arg/Arg & $4(1)$ & $0(0)$ \\
Allele & & $253(92)$ \\
Trp & $699(90)$ & $21(8)$ \\
Arg & $75(10)$ &
\end{tabular}

Data are presented as $n$ or $n(\%)$. Trp: tryptophan; Arg: arginine. variant of the ADRB3 gene upon the prevalence of obesity, insulin resistance or hypertension could be demonstrated.

\section{DISCUSSION}

The present study provides two findings of interest. First, the genotypic and allelic frequencies of the ADRB3 gene variants observed in Spanish patients with OSAS did not differ from those in healthy controls of the same ethnic origin. Secondly, BMI was significantly greater in those patients with OSAS who carried the Arg variant of the ADRB3 gene (Trp/Arg and Arg/ Arg genotypes) than in those with the Trp/Trp genotype. These two observations suggest that the Trp64Arg polymorphism is not associated with the development of OSAS in this Spanish population, but may favour the development of obesity in patients who already suffer OSAS. Consistent with this hypothesis, a previous study has recently shown an independent effect of this polymorphism on BMI in Chinese patients with OSAS [18].

The ADRB3 is mainly expressed in adipose tissue and contributes to population variations in energy expenditure and body fat distribution [6]. A missense mutation of the gene (Trp64Arg) has been associated with increased BMI and an enhanced capacity to gain weight [8]. However, studies carried out in different ethnic groups have reported conflicting results concerning the effect of the Trp64Arg ADRB3 polymorphism on body weight [14, 21-23]. In general, meta-analyses are consistent with a small effect of the Arg64 mutation on BMI $[17,24]$. Although the relevance of this polymorphism to human obesity remains the subject of debate, an important finding is that the Trp64Arg polymorphism is common in diverse populations. Thus, even if the biological effect is small in absolute terms, it may still account for significant population-based attributable risk of obesity [7].

There are several ways of exploring the influence of a genetic background on the phenotypic expression of a given trait. The study of the allelic frequency and prevalence of a given single nucleotide polymorphism are among the most commonly used. In the present study, the allelic frequency of the Arg64 allele was similar between patients with OSAS and controls (table 2). The fact that it was similar in obese and nonobese patients (versus obese and nonobese controls, respectively; table 3) suggests that this polymorphism is not a major determinant of OSAS. However, the observation that patients with OSAS carrying the Arg64 variant had higher BMI than those with the Trp64 variant is consistent with this polymorphism facilitating the development of obesity in patients who, for other reasons, have developed OSAS.

The molecular mechanisms underlying the association of the Trp64Arg polymorphism with various physiological phenotypes are still unclear [7]. Recent evidence suggests that the Arg64 ADRB3 variant has additive and interactive effects with a number of other candidate gene variants, such as the uncoupling protein 1 and 2 genes and lipoprotein lipase gene [25-27]. Furthermore, it has been suggested that the sleep disruption that characterises OSAS may influence the expression of these genes and thus the relative importance of a variant at these loci in determining the obesity risk [5].

Studies that have examined the association between the Trp64Arg polymorphism and different comorbid conditions 


\begin{tabular}{|c|c|c|c|c|c|c|c|c|}
\hline \multirow[t]{3}{*}{ TABLE 3} & $\begin{array}{l}\text { y-obes } \\
\text { onoea }\end{array}$ & $\begin{array}{l}\text { teraction } \\
\text { drome }(\mathrm{O}\end{array}$ & $\begin{array}{l}\text { ginine (Arg) } 64 \\
\text { and controls }\end{array}$ & ant of $\beta_{3}$ & reners & ceptor g & patients with & uctive \\
\hline & \multicolumn{4}{|c|}{ Nonobese } & \multicolumn{4}{|c|}{ Obese } \\
\hline & OSAS & Controls & RR (95\% Cl) & $p$-value & OSAS & Controls & RR (95\% Cl) & $p$-value \\
\hline Subjects $n$ & 155 & 88 & & & 231 & 49 & & \\
\hline
\end{tabular}

associated with obesity, such as insulin resistance and hypertension, have produced inconsistent results [13-15]. In the present study, it was found that the Trp64Arg polymorphism was not associated with glucose levels, lipid concentrations and insulin resistance in patients with OSAS. Furthermore, AHI and blood pressure did not differ between genotypes. These results are in keeping with previous studies reporting that the Arg64 mutation can be associated with obesity independent of blood lipid or glucose levels [12].

\section{Potential limitations}

Studies carried out in different ethnic groups have reported conflicting results regarding the effect of the Arg64 ADRB3 variant on body weight [14, 21-23]. Although the present results are in concordance with other studies in Mediterranean Spanish populations [27], the present findings may be confounded by inadequately controlled risk factors, such as nutritional status, physical activity and the interaction between the ADRB3 gene and other gene variants. Thus further studies in different sample populations are required in order to

\begin{tabular}{|c|c|c|c|}
\hline \multirow[t]{2}{*}{ TABLE } & \multicolumn{3}{|c|}{$\begin{array}{l}\text { Clinical and biochemical characteristics of } \\
\text { obstructive sleep apnoea syndrome patients } \\
\text { according to presence of arginine } 64 \text { variant of } \\
\beta_{3} \text {-adrenergic receptor gene }\end{array}$} \\
\hline & & No mutation & Mutation \\
\hline \multicolumn{2}{|l|}{ Genotype } & Trp/Trp & Trp/Arg or Arg/Arg \\
\hline \multicolumn{2}{|l|}{ Subjects $\mathrm{n}$} & 316 & 71 \\
\hline \multicolumn{2}{|l|}{ AHI } & $51 \pm 23$ & $50 \pm 27$ \\
\hline \multicolumn{2}{|l|}{ BMI } & $31.5 \pm 5.6$ & $33.5 \pm 5.7^{\star \star}$ \\
\hline \multicolumn{2}{|c|}{ SBP $\mathrm{mmHg}$} & $133 \pm 17$ & $133 \pm 15$ \\
\hline \multicolumn{2}{|c|}{ DBP $\mathrm{mmHg}$} & $83 \pm 12$ & $83 \pm 13$ \\
\hline \multicolumn{2}{|c|}{ Glucose $\mathrm{mg} \cdot \mathrm{dL}^{-1}$} & $107 \pm 23$ & $108 \pm 23$ \\
\hline \multicolumn{2}{|c|}{ Triglycerides $\mathrm{mg} \cdot \mathrm{dL}^{-1}$} & $162 \pm 120$ & $167 \pm 109$ \\
\hline \multicolumn{2}{|c|}{ Cholesterol $\mathrm{mg} \cdot \mathrm{dL}^{-1}$} & $212 \pm 42$ & $210 \pm 38$ \\
\hline \multicolumn{2}{|c|}{$\mathrm{HDL}-\mathrm{C} \mathbf{m g} \cdot \mathrm{dL}^{-1}$} & $51 \pm 13$ & $49 \pm 10$ \\
\hline \multicolumn{2}{|c|}{ Insulin $\mu \mathrm{U} \cdot \mathrm{mL}^{-1}$} & $16 \pm 14$ & $18 \pm 10$ \\
\hline \multicolumn{2}{|c|}{ HОMA index } & $4.5 \pm 3.9$ & $4.8 \pm 2.9$ \\
\hline
\end{tabular}

Data are presented as mean $\pm \mathrm{SD}$. AHI: apnoea/hypopnoea index; BMI: body mass index; SBP: systolic blood pressure; DBP: diastolic blood pressure; HDL-C: high-density lipoprotein-cholesterol complex; HOMA: homeostasis model assessment. ${ }^{* *}: \mathrm{p}<0.01$. determine the independent or possible synergistic effect of these polymorphisms on obesity in OSAS.

\section{Conclusion}

In conclusion, the present results do not support a role of the arginine 64 allele of the $\beta_{3}$-adrenergic receptor gene in the pathogenesis of obstructive sleep apnoea syndrome, but show that its presence in those patients who have already developed obstructive sleep apnoea syndrome is associated with a greater tendency to develop obesity.

\section{ACKNOWLEDGEMENTS}

The authors would like to thank both the obstructive sleep apnoea syndrome patients and controls for their willingness to participate in the present research study, and the nursing staff of the sleep units of the various participating hospitals for their help during the course of the study.

\section{REFERENCES}

1 Douglas NJ, Polo O. Pathogenesis of sleep apnoea/ hypopnoea syndrome. Lancet 1994; 344: 653-655.

2 Young T, Palta M, Dempsey J, Skatrud J, Weber S, Badr S. The occurrence of sleep-disordered breathing among middle-aged adults. N Engl J Med 1993; 328: 1230-1235.

3 Rajala R, Partinen M, Sane T, Pelkonen R, Huikuri K, Seppalainen AM. Obstructive sleep apnoea syndrome in morbidly obese patients. J Intern Med 1991; 230: 125-129.

4 Redline S, Tishler PV. The genetics of sleep apnoea. Sleep Med 2000; 4: 583-602.

5 Patel SR. Shared genetic risk factors for obstructive sleep apnoea and obesity. J Appl Physiol 2005; 99: 1600-1606.

6 Lowell BB, Bachman ES. $\beta$-Adrenergic receptors, dietinduced thermogenesis, and obesity. J Biol Chem 2003; 278: 29385-29388.

7 Shuldiner AR, Sabra M. Trp64Arg $\beta_{3}$-adrenoceptor: when does a candidate gene become a disease-susceptibility gene? Obes Res 2001; 9: 806-809.

8 Clement K, Vaisse C, Manning BS, et al. Genetic variation in the $\beta_{3}$-adrenergic receptor and an increased capacity to gain weight in patients with morbid obesity. $N$ Engl J Med 1995; 333: 352-354.

9 Arner $P$. The $\beta_{3}$-adrenergic receptor - a cause and cure of obesity? N Engl J Med 1995; 333: 382-383.

10 Strazzullo P, Iacone R, Siani A, et al. Relationship of the Trp64Arg polymorphism of the $\beta_{3}$-adrenoceptor gene to 
central adiposity and high blood pressure: interaction with age. Cross-sectional and longitudinal findings of the Olivetti Prospective Heart Study. J Hypertens 2001; 19: 399-406.

11 Hallman DM, Srinivasan SR, Chen W, Boerwinkle E, Berenson GS. The $\beta_{2}$-adrenergic receptor Arg16-gly polymorphism and interactions involving $\beta_{2^{-}}$and $\beta_{3}$-adrenergic receptor polymorphisms are associated with variations in longitudinal serum lipid profiles: the Bogalusa Heart Study. Metabolism 2004; 53: 1184-1191.

12 Hao K, Peng S, Xing $H$, et al. $\beta_{3}$-Adrenergic receptor polymorphism and obesity-related phenotypes in hypertensive patients. Obes Res 2004; 12: 125-130.

13 Urhammer SA, Clausen JO, Hansen T, Pedersen O. Insulin sensitivity and body weight changes in young white carriers of the codon 64 amino acid polymorphism of the $\beta_{3}$-adrenergic receptor gene. Diabetes 1996; 45: 1115-1120.

14 Walston J, Silver K, Bogardus C, et al. Time of onset of noninsulin-dependent diabetes mellitus and genetic variation in the $\beta_{3}$-adrenergic-receptor gene. $N$ Engl J Med 1995; 333: 343-347.

15 Widen E, Lehto M, Kanninen T, Walston J, Shuldiner AR, Groop LC. Association of a polymorphism in the $\beta_{3^{-}}$ adrenergic-receptor gene with features of the insulin resistance syndrome in Finns. N Engl J Med 1995; 333: 348-351.

16 Frederiksen L, Brodbaek K, Fenger M, et al. No interactions between polymorphisms in the $\beta_{3}$-adrenergic receptor gene and the PPAR- $\gamma$ gene on the risk of the insulin resistance syndrome in the Danish MONICA cohort. Diabetologia 2003; 46: 729-731.

17 Kurokawa N, Nakai K, Kameo S, Liu ZM, Satoh H. Association of BMI with the $\beta_{3}$-adrenergic receptor gene polymorphism in Japanese: meta-analysis. Obes Res 2001; 9: 741-745.

18 Zhang LQ, Yao WZ, He QY, Wang YZ, Ren B, Lin YP. [Polymorphisms in the $\beta_{2}$ and $\beta_{3}$ adrenergic receptor genes in obstructive sleep apnoea/hypopnoea syndrome.] Zhonghua Nei Ke Za Zhi 2005; 44: 333-336.

19 Matthews DR, Hosker JP, Rudenski AS, Naylor BA, Treacher DF, Turner RC. Homeostatic model assessment: insulin resistance and B-cell function from fasting glucose and insulin concentrations in man. Diabetologia 1985; 28: 412-419.

20 Vogel F, Motulsky AG, eds. Human Genetics: Problems and Approaches. Berlin, Springer Verlag, 1997.

21 Urhammer SA, Hansen T, Borch-Johnsen K, Pedersen O. Studies of the synergistic effect of the Trp/Arg64 polymorphism of the $\beta_{3}$-adrenergic receptor gene and the -3826 $A \rightarrow G$ variant of the uncoupling protein- 1 gene on features of obesity and insulin resistance in a population-based sample of 379 young Danish subjects. J Clin Endocrinol Metab 2000; 85: 3151-3154.

22 Vieira-Filho JP, Reis AF, Kasamatsu TS, et al. Influence of the polymorphisms Tpr64Arg in the $\beta_{3}$-adrenergic receptor gene and Pro12Ala in the PPAR $\gamma 2$ gene on metabolic syndrome-related phenotypes in an indigenous population of the Brazilian Amazon. Diabetes Care 2004; 27: 621-622.

23 Ueda K, Tanizawa Y, Oota $\mathrm{Y}$, et al. Prevalence of the Trp64Arg missense mutation of the $\beta_{3}$-adrenergic receptor gene in Japanese subjects. Metabolism 1997; 46: 199-202.

24 Allison DB, Heo M, Faith MS, Pietrobelli A. Meta-analysis of the association of the Trp64Arg polymorphism in the $\beta_{3}$ adrenergic receptor with body mass index. Int J Obes Relat Metab Disord 1998; 22: 559-566.

25 Sivenius K, Valve R, Lindi V, Niskanen L, Laakso M, Uusitupa M. Synergistic effect of polymorphisms in uncoupling protein 1 and $\beta_{3}$-adrenergic receptor genes on long-term body weight change in Finnish type 2 diabetic and non-diabetic control subjects. Int J Obes Relat Metab Disord 2000; 24: 514-519.

26 Valve R, Heikkinen S, Rissanen A, Laakso M, Uusitupa M. Synergistic effect of polymorphisms in uncoupling protein 1 and $\beta_{3}$-adrenergic receptor genes on basal metabolic rate in obese Finns. Diabetologia 1998; 41: 357-361.

27 Corella D, Guillen M, Portolés J, et al. Gender specific associations of the Trp64Arg mutation in the $\beta_{3}$-adrenergic receptor gene with obesity-related phenotypes in a Mediterranean population: interaction with a common lipoprotein lipase gene variation. J Intern Med 2001; 250: 348-360. 